UDC: 159.923 .2

DOI: https://doi.org/10.24195/2414-4665-2017-3-16

\author{
Anna Shydelko, \\ PhD (Candidate of Sociological Sciences), associate professor, \\ Department of General Psychology, \\ Lviv State University of Internal Affairs, \\ 1, Kryvonosa Str., Lviv, Ukraine
}

\title{
EMOTIONAL STABILITY OF AN INDIVIDUAL: RESEARCH INTO THE TOPIC
}

The paper aims to provide a critical review of the theoretical substantiation of the phenomenon of emotional stability in scientific literature, to categorize scholars' views on psychological peculiarities of emotional stability in adulthood. The study deals with the psychological theories of personality by S. Rubinstein; theories of emotional phenomena by L. Abolin, B. Vardanyan, E. Ilyin, J. Reykowski, O. Chernikova; basic principles of psychocorrection and psycho-social training by T. Yatsenko; manifestations of emotional life by V. Semychenko and others. Emotional stability is considered as a multifaceted integrative personality trait based on four main components - emotional (emotional anxiety or arousal), motivational (power of motivation), intellectual (evaluation, prediction, decision-making in extraordinary situations), typological (peculiarities of the nervous system) - which determine the performance and adequacy of behavior of an individual in solving problems under extreme and stressful conditions. It is an integral part of personal development and adaptation to the world. Emotional stability and emotional vulnerability can be contrasted as opposing properties in terms of their importance for the successful balancing of an individual within the ever-changing environment.

Keywords: emotional stability, an individual, activity, behavior, adulthood, mental state.

\section{Introduction}

Studying the influence of the human emotional sphere on daily activities, their general performance and efficiency as well as adequacy of various behavior patterns is one of the topical issues of modern academic and research psychology. One of the key prerequisites for the successful solution of basic life tasks as well as mental and physical health maintenance is emotional stability of an individual.

The study of emotional stability engages researchers of genetic, differential, age and social, educational as well as aviation, engineering, military, sports psychology, etc.

Emotional stability was singled out into an independent aspect following a fundamental research by L. Abolin (1987) who claims it is a systemic quality of an individual facilitating determination and self-regulation of behavior as well as high productivity in stressful situations [1].

Other researchers defined emotional stability as an integral feature of an individual (mental state) in conjunction with emotional, volitional, intellectual, motivational components of mental activity, which ensures successful achievement of goals in difficult situations [4].

Polish researcher J. Reykowski [12] noted that a person can be considered emotionally stable in the following ways: 1) if the emotional arousal does not exceed an acceptable level despite the strongest stimulation; 2) if there is no violation of behavior patterns despite the strongest emotional arousal. The scholar distinguished the following three main approaches to the study of emotional stability: physiological (to assess how emotional stability depends on the characteristics of the nervous system); structural (to determine regulatory structures of an indi- vidual); regulatory (to disclose a special self-control mechanism).

L. Dyka believes that adapting to difficult environmental conditions is a creative process which promotes the development of new integrative personal qualities which contribute to the increasing of adaptability and the ability to cope with stress under extreme conditions [5].

It can therefore be concluded that the formation of adaptive and maladaptive behavior in extreme conditions is primarily influenced by integrative activities such as emotional stability/vulnerability of an individual; moreover, their activation may lead to either adequate, predictable and balanced behavior, or irrational, inappropriate, aggressive, often unpredictable and sometimes tragic conduct. In this respect emotional stability should be considered as an integrative property or quality of a personality, characterized by interaction of emotional, volitional, intellectual and motivational components.

The paper aims to provide a critical review of the theoretical substantiation of emotional stability formation in academic literature, to categorize scholars' views on psychological peculiarities of emotional stability in adulthood.

\section{Research methods}

To address the objectives and purpose of the article the following methods were used: theoretical - a systemic and comparative analysis of theoretical works by Ukrainian and foreign scholars to identify common and divergent features of emotional sphere interpretation; generalization and systematization of psychological, sociological, educational literature on the subject to clarify the essence of emotional stability, discern its causes, manifestations and implications for an individual's life; analytical - to ana- 
lyze potential emotional responses to social stress factors and to bring forward a number of scientific abstractions of modern scholars; generalization of theoretical data to draw conclusions.

\section{Discussion}

The personality reaches his/her highest point of development in adulthood. Adulthood indicates personal maturity at the peak of its potential and capabilities. Being the longest period of an individual's conscious life, this stage is worth careful examination. During the outlined period, an individual is able to interact harmoniously with the society, understand his/her motives and ways of their implementation, fulfill his/her professional ambitions, procreation and family function, etc. However, as the psychophysical parameters get weaker and the social status and daily routine gradually change, this period appears to be marked by various crises.

According to French psychologist E. Claparede adulthood is maturity of an individual characterized by cessation of the development, as well as "stiffening" of his/her mental function.

German psychologist H. Ebbinghaus examined the regularities and patterns (processes of learning and forgetting) of his own memory. He concluded that the mature age (25-50 yrs) remains unchanged with respect to the above-mentioned mental activity.

W. James, an American psychologist and philosopher, argued that at the age of 25 an individual's ability to produce new ideas slows down, youthful curiosity decreases, mental capacity stops its development and the desire for assimilation (typical for those under 25) becomes exhausted. However, numerous constructive studies, including those of adulthood, have changed the views of many scholars. It has been found that during the productive life phase the process of human development does not stop, and personality keeps developing as an independent self-sustaining system.

Emotional stability is the subject of research in the psychological theory of personality by S. Rubinstein; theories of emotional phenomena by L. Abolin, B. Vardanyan, E. Ilyin, J. Reykowski, O. Chernikova; the psychological theory by K. Platonov; basic principles of psychocorrection and psycho-social training by T. Yatsenko $[1 ; 3 ; 6 ; 12 ; 15 ; 16]$.

Studying manifestations of emotional life B. Semychenko notes that "their division into moods, feelings, affects, emotions, passions, stress, emotional states is quite conventional since emotional states comprise emotions and every emotion in certain circumstances appears as a mental state" $[13$, p. 52]. Thus, emotional stability consists of psychological and biological components, out of which the latter contributes to the timely and full mobilization of the organism in extreme situations. So it is worth interpreting emotional stability as an organizational and motivational factor of human behavior, a source of personal development and relationship with the outside world.

Having analyzed the relevant studies we are able to highlight six directions within which emotional stability is considered in terms of various emotional phenomena involvement.

The first direction (L. Abolin, B. Vardanyan, J. Reykowski, A. Chernikova) is based on the conviction that a mental process as a sign of particular activity does not depend on other mental processes and has unique features $[1 ; 3 ; 12 ; 15]$.

Thus, J. Reykowski notes that emotional stability is "an individual's ability to hold his/her own under conditions of social instability, have certain mechanisms of protection against the actions that do not go in line with his/her views, beliefs and outlook in general" [12].

Instead, O. Chernikova distinguishes a) relative stability of optimally intense emotional reactions and b) stability of qualitative emotional states or, in other words, a steady orientation of emotional experiences towards positive resolution of future issues [15].

L. Abolin and B. Vardanyan hold a slightly different position concerning this issue. They consider emotional stability in terms of polarity and intensity of emotions as determining activity under tense circumstances $[1 ; 3]$. In particular, B. Vardanyan notes that emotional stability is "a property that provides a harmonious ratio between all components of activity in emotiogenic situations and thus contributes to its successful accomplishment; resistance to emotiogenic factors that have a negative impact on the mental state, the ability to control and suppress emerging asthenic emotions which ensure successful implementation of necessary actions" [3, p. 215].

Conversely, J. Reykowski believes emotional stability is a specific measure of emotional arousal and emotional sensitivity of an individual. He goes on to single out two levels of the process: "1) a person is emotionally stable if the emotional arousal does not exceed the threshold despite strong stimuli; 2) a person is emotionally stable if, despite strong emotional arousal, no violation of behavior patters is observed" [12, p. 162].

So, supporters of the outlined direction view emotional stability as a multifunctional, harmonious system of emotional adjustment of a personality. At the same time it is considered to be one of the psychological factors of reliability, effectiveness and success in stressful situations, a phenomenon of ethical constancy and social stability depending on intensity and polarity of emotional reactions of a socialized individual.

The second direction in the Ukrainian psychology (E. Ilyin, A. Nosenko) is represented by the physiological (interdependence between emotional stability and properties of the nervous system) and structural (justification of regulatory structures of personality) approaches as well as a substantiation of the self-control mechanism [6;8]. According to E. Ilyin, the occurrence of emotional stability is associated with the emergence of a particular emotional state and powerful emotiogenic situation. Moreover, the scholar stresses that "there is no "universal" emotional stability and it varies substantially depending on the nature of an emotiogenic factor" [6, p. 152].

Therefore, emotional stability is regarded as an indi- 
vidual's resistance to a certain emotiogenic factor encompassing neurodynamic and temperamental characteristics as manifestations of low emotional sensitivity which depends on the peculiarities of the nervous system. In addition, emotional stability also implies a certain degree of emotional arousal which does not affect an individual's behavior but rather contributes to effective operation in various everyday situations.

The third direction according to which emotional stability is defined as a manifestation of psychoregulatory functions of emotions and emotional states (V. Pysarenko, O. Prokhorov, etc.) $[9 ; 10 ; 11]$ is of utmost importance. In particular, V. Pysarenko believes that emotional stability is "an ability to respond to tense situations by going through such changes in one's emotional state which do not decrease but boost performance" [9]. O. Prokhorov interprets emotional stability as "consistency and stability in the expression of emotions and emotional states" [11, p. 87]. So, here emotional stability is also considered as a property of an individual which ensures the stability of psychoemotional arousal when exposed to various negative emotions.

According to the fourth direction, emotional stability is based on cooperation and complementarity of psychological processes. Followers of this approach describe emotional stability as an ability to possess emotions of different nature that arise in the course of professional activities and strengthen or weaken, hinder or support each other etc.

Emotional stability is regarded as an individual's integrative ability which reflects dynamic interaction between mental processes related to emotiogenic nature of activity. Firstly, it is harmony of sensuous, resilient, mental and motivational components of internal mental organization which ensures accomplishment of daily tasks. In this context the determining factor of emotional stability is the effectiveness of an individual's performance in a meaningful situation resulting into the success or failure to satisfy the needs (an emotiogenic situation). Thus emotional stability is considered as a positive personality trait, manifested in the moments of taking responsibility, achieved in case of optimal intensity, characterized by constancy and determination to achieve daily goals.

The fifth direction relates to the theory of attitude (D. Uznadze), according to which the formation of its general purposeful and steady nature is associated with its activity [14]. The system of person's attitudes involves conceptual, target and operational ones. Conceptual attitudes represent an individual's stance on the world, target ones arise in response to obstructed activity while those of the operational kind originate under "standard" conditions and enable a usual pattern of conduct or programme it to match a certain kind of activity which ensures "solution of certain tasks on the basis of past behavioral experience in similar situations" [14, p. 225]. So, proponents of this approach understand emotional stability as a system of attitudes which account for its steady nature and represent an individual's psycho-conceptual attitude towards activity.
The sixth direction is represented by the information and cyber theory of complex systems stability formulated by E. Krupnik [7]. The scholar defines emotional stability as a balance and an optimal ratio between dialectically conflicting psychological structures of a personality, as well as "a synthetic category of two mental manifestations of an individual - stability and variability" [7, p. 49]. So, emotional stability is a harmonious dynamic interrelation of mental structures which represent personality, consciousness, activity. The main precondition for the formation of psycho-emotional stability is individual consciousness in all its everyday manifestations.

When assessing emotional stability one may also resort to the theory of the so-called self-efficacy or subjective effectiveness and confidence in it. The assessment by an individual of his/her behavior and its effectiveness as well as reactions to certain events activates a personal scheme of competence and skills. Thus, confidence in one's own ability to achieve a desired result under new conditions which stems from similar experiences in the past can be transferred to each new situation as the previously acquired patterns of behavior are reproduced. That is, if an individual has experienced certain extreme situations before, it is likely to evoke productive expectations of success in overcoming new challenges. Consequently, such a person takes the initiative and persistence to overcome stress in extreme conditions [2]. Confidence in one's own effectiveness gives hope of success, even if it is only an attempt to cope with a difficult situation. On the contrary, lack of confidence in self-efficacy when a person does not feel enough strength to cope with difficult situations can lead to a reassessment of the situation as such that cannot be managed and thus add to the stress. As a result, confidence in one's own effectiveness is a crucial prerequisite for successful behavior of an individual in stressful situations.

\section{Conclusions}

Emotional stability is a multifaceted integrative personality trait based on four main components - emotional (emotional anxiety or arousal), motivational (power of motivation), intellectual (evaluation, prediction, decisionmaking in extraordinary situations), typological (peculiarities of the nervous system) - which determine the performance and adequacy of behavior of an individual in solving problems under extreme and stressful conditions. Emotional stability is an integral part of personal development and adaptation to the world.

Emotional stability and emotional vulnerability can be contrasted as opposing properties in terms of their importance for the successful balancing of an individual within the ever-changing environment. This balancing is aimed at preserving or reproducing a certain attitude such as adjustment to new stabilized conditions.

Our further research is planned to be focused on the empirical disclosure of features of emotional stability in adulthood in order to develop practical recommendations for its formation. 


\section{REFERENCES}

1. Abolin, L. M. Emotsionalnaya ustoychivost i puti ee povysheniya Retrieved from: www.voppsy.ru/issues/1989/894/894141.htm. [in Russian].

2. Arshava, I. F. (2006). Emotsiina stiikist liudyny ta ii diahnostyka [Emotional stability of a person and its diagnostics]. Dnipropetrovsk: DNU [in Ukrainian].

3. Vardanyan, B. Kh. (1983). Mekhanizmy regulyatsii emotsionalnoy ustoychivosti: kategorii, printsipy $i$ metody psikhologii. Psikhicheskie protsessy [Mechanisms of regulation of emotional stability: categories, principles and methods of psychology. Mental processes]. Moscow: Nauka [in Russian].

4. Denisov, V. A. (1985). Sravnitelnyy analiz operatorskoy deyatelnosti i ee sryvov [Comparative analysis of operator activity and its disrupt]. Psikhologicheskie problemy deyatelnosti v osobykh usloviyakh - Psychological problems of activity in special conditions: collection of scientific articles, (pp. 38-62) [in Russian].

5. Dikaya, L. G. (1991). Deyatelnost i funktsionalnoe sostoyanie: aktivatsionyy komponent deyatelnosti [Activity and functional state: an activating component of activity]. Psikhologicheskie problemy professionalnoy deyatelnosti - Psychological problems of professional activity, (pp. 93-111) [in Russian].

6. Ilyin, E. P. (2008). Yemotsii i tshuvstva [Emotions and feelings]. St. Petersburg: Peter [in Russian].

7. Krupnik, E.P. (2006). Natsionalnoe samosoznanie. Vvedenie $v$ problemu [National selfawareness. Introduction to the problem]. Moscow: Moscow Psychological and Social Institute [in Russian].

8. Nosenko, E. L., Arshava, I. F. (2006). Systemnyi pidkhid do vyvchennia stiikosti liudyny u svitli novitnikh doslidzhen emotsii i psykhichnykh staniv [System approach to studying human stability in terms of innovative

\section{ЛІТЕРАТУРА}

1. Аболин Л. М. Эмоциональная устойчивость и пути ее повышения / Л. М. Аболин [Електронний pecypc]. - $\quad$ Режим доступу http://www.voppsy.ru/issues/1989/894/894141.htm. Назва $з$ екрана // Сайт журнала «Вопросы психологии» в девятнадцатилетнем ресурсе (1980-1998 гг.).

2. Аршава І.Ф. Емоційна стійкість людини та іï діагностика : монографія / I. Ф. Аршава. - Дніпропетровськ : Вид-во ДНУ, 2006. - 336 с.

3. Варданян Б. Х. Механизмы регуляции эмоциональной устойчивости : категории, принципы и методы психологии. Психические процессы / Б. Х. Варданян. - М. : Наука, 1983. - 542 с.

4. Денисов В. А. Сравнительный анализ операторской деятельности и ее срывов / В. А. Денисов // Психологические проблемы деятельности в особых условиях : сборник научных ст. - М. : Наука, 1985. C. $38-62$.

5. Дикая Л. Г. Деятельность и функциональное состояние : активационый компонент деятельности / studies of emotions and psychological states]. $Z b$. nauk. prats in-tu psykholohii im. H. S. Kostiuka APN Ukrainy Collection of scientific works of $H$. Kostiuk Institute of Psychology NAES of Ukraine, 5, 229-243 (Vol. 8) [in Ukrainian].

9. Pisarenko, V. M. (1986). Rol psikhiki v obespechenii emotsionalnoi ustoichivosti cheloveka [The role of psyche in providing human emotional stability]. Psikhologicheskii zhurnal - Psychological journal, 1, 6273 (Vol. 7) [in Russian].

10. Prokhorov, A. O. (1999). Neravnovesnye psikhicheskie sostoyaniya [Unstable psychic states]. Psikhologicheskii zhurnal - Psychological journal, 2, 115-124 [in Russian].

11. Prokhorov, A. O. (1988). Psikhologiia neravnovesnykh sostoianii [Psychology of moral states]. Moscow: Institut psikhologii RAN [in Russian].

12. Reikovskii, Ya. (1999). Eksperimentalnaya psikhologiya emotsiy [Experimental psychology of emotions]. Moscow: Progress [in Russian].

13. Semichenko, V. A. (2001). Psykholohiia osobystosti [Psychology of personality]. Kyiv: vid. O. M. Eshke [in Ukrainian].

14. Uznadze, D. N. (2001). Psikhologiya ustanovki [Psychology of attitude]. Saint Petersburg: Piter [in Russian].

15. Chernikova, O. A. Emotsionalnye sostoianiia $v$ sporte [Emotional states in sports]. Retrieved from: http://www.studfiles.ru/preview/5458217/page:11. [in Russian].

16. Yatsenko, T. S. (2004). Teoriia i praktyka hrupovoi psykhokorektsii: Aktyvne sotsialno-psykholohichne navchannia: navchalnyi posibnyk [Theory and practice of group psychocorrection: active psychosocial trainings: study guide]. Kyiv: Vyshcha shkola [in Ukrainian].

Л. Г. Дикая // Психологические проблемы профессиональной деятельности : сборник ст. / [отв. ред. Л. Г. Дикая, А. Н. Занковский]. - М. :Наука, 1991. С. 93-111.

6. Ильин Е. П. Эмоции и чувства : учебное пособие / Е. П. Ильин. - 2-е изд. - СПб. : Питер, 2008. $783 \mathrm{c}$.

7. Крупник Е. П. Национальное самосознание. Введение в проблему : монография / Е. П. Крупник. М. : Московский психолого-социальный институт, 2006. - $144 \mathrm{c}$.

8. Носенко Е. Л. Системний підхід до вивчення стійкості людини у світлі новітніх досліджень емоцій і психічних станів / Е. Л. Носенко, І. Ф. Аршава // Зб. наук. праць ін-ту психології ім. Г. С. Костюка АПН України. - Т. 8. - Вип. 5. - 2006. - С. 229-243.

9. Писаренко В. М. Роль психики в обеспечении эмоциональной устойчивости человека / В. М. Писаренко // Психологический журнал. - 1986. - Том 7. - № 1 январь-февраль. - С. 62-73. 
10. Прохоров А. О. Неравновесные психические состояния / А. О. Прохоров // Психологический журнал. - 1999. - № 2. - С. 115-124.

11. Прохоров А. О. Психология неравновесных состояний / А. О. Прохоров. - М. : Институт психологии РАН, 1988. - 152 с.

12. Рейковский Я. Экспериментальная психология эмоций / Я. Рейковский. - М. : Прогресс, 1999. $472 \mathrm{c}$.

13. Семиченко В. А. Психологія особистості / В. А. Семиченко. - К. : вид. О. М. Ешке, 2001. - 427 с.
14. Узнадзе Д. Н. Психология установки / Д. Н. Узнадзе. - СПб. : Питер, 2001. - 416 с.

15. Черникова О. А. Эмоциональные состояния в спорте / О. А. Черникова [Електронний ресурс]. Режим доступу http://www.studfiles.ru/preview/5458217/page:11.

16. Яценко Т. С. Теорія і практика групової психокорекції : Активне соціально-психологічне навчання : навчальний посібник / Т. С. Яценко. - К. : Вища школа, 2004. - 697 с.

\section{Анна Володимирівна Шиделко, кандидат соиіологічних наук, дочент кафедри загальної психології, Львівський державний університет внутрішніх справ, вул. Кривоноса, 1, м. Львів, Украйна}

\section{ЕМОЦІЙНА СТІЙКІСТЬ ОСОБИСТОСТІ: НАУКОВІ РОЗВІДКИ}

У статті представлено теоретичний аналіз формування емоційної стійкості особистості. Зосереджено увагу на усвідомленому етапі життя особистості - дорослому віці - як періоду зрілості людини, розквіту їі потенціалу і можливостей. Розглянуто проблему емоційної стійкості у психологічних теоріях особистості С. Рубінштейна; теоріях емоційних явищ Л. Аболіна, Б. Варданяна, Є. Ільїна, Я. Рейковського, О. Черникової; основних принципах психокорекційної роботи та організації соціально-психологічних тренінгів Т. Яценко; проявів емоційного життя людини В. Семиченко та ін. Подано визначення поняття «емоційна стійкість». Розкрито шість напрямів дослідження емоційної стійкості. Перший напрям грунтується на розумінні того, що психічний процес, як момент конкретної діяльності особистості, $є$ незалежним від інших психічних процесів і має своєрідні особливості. Другий аналізує фізіологічний (за яким вивчають залежність емоційної стійкості від властивостей нервової системи) і структурний (за яким обгрунтовують регуляторні структури особистості) підходи, а також дію механізму самоконтролю. Третій напрям обгрунтовує емоційну стійкість особистості як прояв психорегуляційної функції емоцій та емоційних станів. Емоційна стійкість на четвертому напрямі дослідження грунтується на взаємодії й обопільності психічних процесів. П'ятий напрям оснований на позиції теорії установки (Д. Узнадзе), де формування іiі загальної спрямованості пов'язано з діяльністю, що додає їй стійкого, стабільного характеру. Констатовано, що емоційна стійкість - це багатосистемна, інтегральна риса особистості, основана на чотирьох головних компонентах - емоційному, мотиваційному, інтелектуальному, типологічному, які зумовлюють продуктивність діяльності й адекватність поведінки особистості під час вирішення завдань в умовах екстремальних і стресових дій. Емоційна стійкість $\epsilon$ невід'ємною складовою частиною і розвитку особистості та її адаптації у світі.

Ключові слова: емоційна стійкість, особистість, діяльність, поведінка, дорослий вік, психіка.

Submitted on February, 24, 2017

Doctor of Psychology V. Klymchuk 